\title{
IAMJ
}

INTERNATIONAL

AYURVEDIC

MEDICAL JOURNAL

ISSN: 2320-5091

Impact Factor: 6.719

\section{RUDRA PARPATI: AN AYURVEDIC HERBO - MINERAL DRUG REVIEW}

\section{Priyanka. B. Patil ${ }^{1}$, Usha $\mathbf{M}^{2}$, Ravi R Chavan ${ }^{3}$}

13rd Year PG Scholar, Dept of RS \& BK, Taranath Government Ayurvedic Medical College, Bellary, Karnataka, India

${ }^{2}$ Assistant Professor, PG Studies, Dept of RS \& BK, Taranath Government Ayurvedic Medical College, Bellary, Karnataka, India

${ }^{3}$ Professor \& HOD, PG Studies, Dept of RS \& BK, Taranath Government Ayurvedic Medical College, Bellary, Karnataka, India

Corresponding Author: patilpreeti450@gmail.com

\section{https://doi.org/10.46607/iamj3509082021}

(Published Online: August 2021)

Open Access

(C) International Ayurvedic Medical Journal, India 2021

Article Received:23/07//2021 - Peer Reviewed: 04/08/2021 - Accepted for Publication: 05/08/2021

\section{Check for updates}

\section{ABSTRACT}

The main objective of this review article is to discuss the therapeutic uses of Rudra Parpati and to discuss the different pharmacological properties and therapeutic uses of isolated constituent drugs of Rudra Parpati. The authentic subject material has been reviewed from Ayurveda and modern medical literature. Different research and review articles were searched in different journals. The subject material has also been searched on the internet. This review is mainly focused on different aspects of herbo mineral Ayurvedic formulation Rudra Parpati. Parpati rasayana is one among Chaturvidha Rasayana Kalpa which is very effective and can be prepared with less effort. In Ayurveda Rudra Parpati is mentioned in the management of Kasa/cough. Though it is popular as only Parpati used in Kharapaka form \& having an indication other than Grahani but still an unexplored treasure with unique therapeutic utility. Hence an attempt has been made to address the therapeutic uses of Rudra Parpati and the probable mode of action of its constituent drugs.

Keywords: Rudraparpati, Vataja Kasa. 


\section{INTRODUCTION}

Rudra Parpati ${ }^{1}$ : Nirukti of word Rudra came from Rudira ${ }^{2}$ which means Rakta, Raktavarna or Agni. So, meaning can be derived as the parpati having red colour. Or Parpati having Tamra \& it's prepared till it attains red colour/ kharapaka hence it has Agnitatva in it.

Rudra parpati is mentioned in kasa rogadhikara in a text Rasakamadhenu. This formulation is familiar as only parpati is indicated to prepare in Kharapaka \& Indicated in Vataja kasa. ${ }^{3}$ Hence this reference is taken for review of this article.

Kasa has been described as 'Release of obstructed Vayu with the production of abnormal sound. This may be dry (without secretions) or productive (with secretions). ${ }^{4}$ Kasa is an independent disorder as well as a symptom of many diseases and if neglected it may result in disease with a poor prognostic condition. Early intervention is necessary in the case of Kasa as it is a potential Nidanarthakara Vyadhi (disease itself become a causative factor for other diseases) to produce Kshaya (depletion of bodily tissues or Dhatus). There are 5 types of kasa explained by Brihatrayees.

1) Vataj Kasa

2) Pittaj Kasa

3) Kaphaj Kasa

4) Kshayaja Kasa

5) Kshataja Kasa

According to Madhava nidana Vataja kasa has lakshanas of Hridaya shoola (chest pain), Murdha shoola (Headache), Parshwashoola (pain in flanks), Udara shoola (abdominal pain), Shankha shoola (pain in the temporal region), Kasatishushkamev (Dry cough), Prasakt vegastu (continuous bouts of cough), Bhinna swara (Hoarseness of voice), Ksheena Bala (Loss of strength). ${ }^{5,6}$

Cough can be correlated to the description of Kasa in Ayurveda. It may be classified as productive or dry as well as acute subacute or chronic. The prevalence of cough in India is $5 \%-10 \% .^{7}$ It is one of the most common presenting complaints $(30 \%)$ in the primary care setting. ${ }^{8}$

Man has been using natural products for combating diseases for ages. Natural products including plants, animals \& minerals have been the basis of the treatment of human diseases. The plant-based, traditional medicine systems continue to play an essential role in health care, with about $80 \%$ of the world's inhabitants relying mainly on traditional medicines for their primary healthcare.

Rudraparpati $^{l}$ an Ayurvedic herbo mineral formulation is indicated in the management of Vataja kasa (Cough). It contains three mineral drugs and six herbal drugs viz Parada (mercury), Gandhaka (Sulphur), Eranda (Calotropesprocera), Adraka (Zingiberofficinale), Bringaraj (Ecliptaalba), Kakamachi (Solanum nigrum), Adrikarnika / Shankhapusphi (convolvulus pluricaulis), Tamra bhasma (incinerated copper) \&Visha (Aconitum Ferox).

Table1: Table showing list of drugs with Quantity

\begin{tabular}{|c|c|c|}
\hline SI No. & Ingredients & Proportion \\
\hline 1. & Parada (mercury) & 1 part \\
\hline 2. & Gandhaka (Sulphur) & 2 parts \\
\hline 3. & Eranda swarasa (Calotropes procera) & Quantity sufficient \\
\hline 4. & Adraka swarasa (Zinziber officinale) & Quantity sufficient \\
\hline 5. & Bringaraj swarasa (Eclipta alba) & Quantity sufficient \\
\hline 6. & Kakamachi swarasa (Solanum nigrum) & Quantity sufficient \\
\hline 7. & Shankhapusphi swarasa (convolvulus pluricaulis & Quantity sufficient \\
\hline 8. & Tamra bhasma (incinerated copper) & $1 / 4^{\text {th }}$ part \\
\hline 9. & Visha(Aconitum Ferox). & $1 / 4^{\text {th }}$ part of the whole quantity \\
\hline
\end{tabular}




\section{Ingredients In Detail}

Shuddha Parada

Rasa - Tiktha, kashaya, katu

Doshaghnata-tridoshahara

Indications - Jwara, Ati Rasayana, Deepana,

Vrushya, Sarva Rogaghna, Kamala, Pleeha, Kushta,

Amavata and Vishanashaka.

\section{Shuddha Gandhaka ${ }^{9}$}

Rasa-katu

Guna-guru, ruksha, teekshna

Veerya - ushna

Vipaka-katu

Doshaghnata - kapha vata shamaka

Uses - agni sandeepana, kushta, pandu, rakta pit-ta, vrana, jwara, daha, grahani,

Eranda $^{10}$

Rasa-Madhura

Guna-Guru, Snigdha, tikshna

Veerya-Ushna

Vipaka-Madhura

Doshaghnata - Vatakaphapittahara

Uses - Shosha shoolagna, Srotoshodhana,

Shwasakasahara, Bastishodhana, Jvara, Amavatahara.

Ardraka ${ }^{11}$

Rasa - Katu

Guna-Guru, Ruksha, Teekshna

Veerya-Ushna

Vipaka-Madhura

Doshaghnata - Kapha vata shamaka

Uses - Agni sandeepna, Vibanda anaha shoolajit,

Jihva kantha vishodhana, Shwasa Kasa hikka ha-ra,

Jwara Grahani.

Bringaraja $^{12}$

Rasa - Katu Tikta

Guna-Ruksha, Laghu

Veerya-Ushna

Vipaka-Katu

Doshaghnata - Kaphavata shamaka

Uses - Keshya, Kasa, Krimi, Shwasa, Kustha,

Shopha, Shoola, Agni sandeepna, Kushta, Pandu,

Rasayan \& Balya.

\author{
Kakamachi $^{13}$ \\ Rasa-Tikta \\ Guna - Laghu, Snigdha \\ Veerya-Anshna \\ Vipaka - Katu \\ Doshagnata - Tridoshahara
}

Uses - Swara \& shukrada, Hikka, Chardi, Shotha,

Kustha, Hridrogahara \& Rasayani.

Shankhapusphi ${ }^{14}$

Rasa - Katu Tikta

Guna - Snigdha

Veerya-Ushna

Vipaka-Madhura

Doshagnata-Pittabalasajit

Uses - Kasahara, Svarya, Medhya, Unmada, Chardi, Visha, Apasmara.

\section{Tamra Bhasma ${ }^{15}$}

Rasa - Tikta, kashaya, madhura

Guna - snigdha

Veerya-Ushna

Vipaka-Amla vipaka

Doshagnata - Pittakaphahara

Uses - Saraka, Lekhana, Vishahara, Apasmara, Malabhedana, Urdvajatru roga.

Visha $^{16}$

Rasa-Madhura

Guna-Laghu, Ruksha, Teekshna, Vyavayi, Vikasi

Veerya-Ushna

Vipaka-Madhura

Karma- Vatakaphahara.

Uses - Jwarahara, Kasa, Shwasa

Prabhava-Rasayana

\section{Method Of Preparation}

Firstly, Kajjali is prepared by triturating 1-part Shuddha Parada and 2-part Shuddha Gandhaka till it becomes black fine powder and all Kajjali Pareeksha are achieved. Mardana is done with swarasa of each drug separately for 1 day i.e. Eranda, Adraka, Kakamachi, Bringaraj \& Shankhapuspi \& triturated till it completely dries.

The mixture is then transferred into an iron vessel which is coated with a thin layer of Ghee from inside and the vessel is then heated. The Ghee melts and gets spread the vessel. Then the mixture containing 
Kajjali is poured into the vessel and heated on mild fire slowly. When the drug sub-stance melts, 1/4th part of Tamra Bhasma is added \& continuously stirred. When the colour turns red it is poured on a banana leaf which is coated al-ready with a thin layer of Ghee placed over cow dung. Another similarly coated leaf is kept on the spread substance and the pressure is applied in one direction once unilaterally. On cooling on its own, the thin crisp wafer i.e, Parpati is collected. Parpati is powdered in Khal-Wa \& 1/4th part (weight of Parpati) Shuddha Vatsanabha Churna is added and powdered and kept in a bottle.

\section{DISCUSSION}

The Yoga Rudraparpati possesses Katu, tikta madhura Rasa, Ushna veerya, Vatakaphahara. Based on properties \& research articles of individual ingredients in Rudraparpati its mode of action in Kasa is drawn out.

Kajjali: It possesses Yogavahi property \& here dwiguna bali jarita kajjali is used which is mentioned as Maha rogavidhoonana ${ }^{17}$ (cures deeper ailments).

Tamrabhasma: Acc to A.P Tamrabhasma is kasa, swasa \& ksayahara. As kasa \& swasa samprapti its udbavasthana is amashaya involvement of pitta is seen. As tamrabasma pittasaraka \& lekhaniya does samprapti vighatana. Because of snighda guna \& ushnaveerya, it excellently combats Vataja Kasa.

An article on the review of research works done on tamrabhasma shows tamrabhasma along with talisadi churna is significant in relieving shwasa ${ }^{18}$. Bhasma along with kantakari increases peak expiratory flow rate \& shown good responses including a reduction in thickening of brochovascular marking of asthma patients ${ }^{19}$.

Vatsanabha: it does Vatakaphanashana, Margavivarana (bronchodialor), Kaphamalan upahanti (mucolytic) \& Ropana activity by the virtue of this it successfully combats the Kasa Swasaroga.

Eranda: is Ushna veerya, Snigdaguna\& does Vatanulomana thus breaks the Samprapti of Kasa. It is Vata kaphahara in nature. It clears channels.
Adraka: Swasa kasahara, Shopha \& Kanta amayapaha. in an experimental study showed components like cital, eucalyptol suppressed tracheal contraction \& showed relaxing effect on airway ${ }^{20}$. Hence, it's a proven bronchodialator. It is also having anti-inflammatory \& antiviral activity.

Bringaraja: It contains coumarin which is responsible for bronchodialotory action. It is antinociceptive ${ }^{21} \&$ antiinflamatory.

Shankhapuspi: Having Ushna \& Snighda guna relieves Vataja Kasa.

Kakamachi: having Tikta \& Snigdha guna. As it contains solanigrine which helps in reducing the coughbouts.

Based on research article bitter taste medicinal drugs having their role in bronchiodialation \& ease the breathing as lungs have receptors of bitter taste drugs. ${ }^{22}$ So Tiktarasa of most of the ingredients here helps in easy Breathing.

\section{MODE OF ACTION}

Shushka Kasa: the Rukshaguna of Vata creates Shuskhata in the concerned area \& Chalaguna of Vata causes repeated bouts of cough resulting in dryness of mouth, chest region which in turn causes Shushka Kasa.

The Sushkata can be rectified by Ushna veerya \& Snigdha guna of drugs Eranda, Tamra, kakamachi\& others.

Prasakta vega: Prasakta vega is satata vega or persistent cough, which occurs due to increased stimulation of vatanadi by chalaguna of vayu.

Coughing episodes can be rectified by the antitussive drugs like Kakamachi \& Shankhapushpi (due to their sedative action) by disrupting the cough reflex, though their exact mechanism is unknown.

Shira, Parshva \& Hritshoola: Due to persistent cough repeated contraction \& relaxation of the muscles increases the pressure in vessels resulting in neuro-muscular irritability \& increases intracranial pressure. This leads to pain in regional muscles \& headache.

Pain can be rectified by the antinociceptive action of Bringaraja\& the Analgesic action of the drugs like 
Aadraka, Visha, Eranda, Kakamachi \& Tamrabhasma.

Swara bheda: Swarabheda is a condition that resulted due to vitiation of Udana vayu. Due to excessive stimulation of recurrent laryngeal nerve as a result of an increase in vibration of vocal cords present in the larynx. This frequent stimulation causes impairment in producing sound resembling a broken bronze vessel

Swarabheda can be rectified by soothing action on the throat muscles by the drugs like Adraka, Eranda \& Kakamachi.

Kshamanana: it refers to a lusterless face (shushkamukha vatena shoshonnatah). Vatavruddi, Balakshaya Dhatuksaya are held responsible for the lusterless face. Here Snigdha guna and Rasayana karma of the drug helps in relieving the symptoms.

\section{CONCLUSION}

It is clear from literature \& research papers that Rudraparpati is an effective drug that can be used in Kasa specially Vataja Kasa. It has broad-spectrum activity in respiratory disorders.

\section{REFERENCES}

1. Sri Mishra Chudamani, Rasakamadhenu, Suvivrtti Hindi commentary of Vaidya Shri Sharma Santosh Kumar. $2^{\text {nd }}$ edition 2003: Varanasi: Chaukhambha Orientalia; Uttarardha, forth chikitsapada, Chapter-34; Verse18-23,77-78pp.

2. Raja Radha kantha Dev. Shabda kalpa Druma, Delhi, Naga Publishers, 2002 (reprint) Vol-4 167-168pp.

3. Sri Mishra Chudamani, Rasakamadhenu, Suvivrtti Hindi commentary of Vaidya Shri Sharma Santosh Kumar. $2^{\text {nd }}$ edition 2003: Varanasi: Chaukhambha Orientalia; Uttarardha, forth chikitsapada, Chapter-34; Verse18-23,77-78pp.

4. Pandit Kashinath Shastri \& Dr GorakhnathChaturvedi, Hindi commentary on Charaka Samhita of Agnivesha revised by Charaka and Dridbala,6 Edition 2009: Chaukhambha Bharti Academy, Varanasi. chikitsasthan chapter 18, 532pp,

5. Upadhya Yadunandanoupadhya: Vidhyotini Hindi commentary on Madhav Nidan Madhukosha vyakhya, 18 Edition: Chaukhamba Prakashan; Kasanidan 11/57, 306-309pp.

6. Pandit Kashinath Shastri \& Dr GorakhnathChaturvedi, Hindi commentary on Charaka Samhita of Agnivesha revised by Charaka and Dridbala. Edition 2009:
Chaukhambha Bharti Academy; Varanasi. chikitsasthan 18/11- 13 .

7. Song W, Chang YS, Faruqi S, Kim JY, Kang MG, Kim S, et al. The global epidemiology chronic cough in adults; a systematic review and meta-analysis. Eur Respir J 2015; 45:1479-1481

8. ApteK,MadasS,BarneM,SalviSprevalenceofcough and its associated diagnosis among 204,912 patients seen in primary care (PC) in India. Eur Respir J 2016;48: PA864

9. Shri Sharma Sadananda. Rasa Tarangini. Hindi translation \& Edited by Pandit Kashinath Shastri.

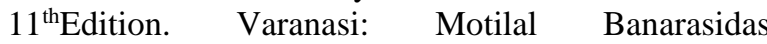
Publication; 2004. $8^{\text {th }}$ Taranga, Verses 36-38.

10. Shastry. J.L.N. Dravyaguna Vijnana. Edition 2006 reprint. Varanasi: Chaukhambha Orientalia; Vol 2 483pp.

11. Ibid 294pp.

12. Ibid $865 \mathrm{pp}$.

13. Ibid 359pp.

14. Ibid $865 \mathrm{pp}$.

15. Shri Sharma Sadananda. Rasa Tarangini. Hindi translation \& Edited by Pandit Kashinath Shastri. $11^{\text {th }}$ Edition. Varanasi: Motilal Banarasidas Publication; 2004. 17 $7^{\text {th }}$ Taranga, Verses 45.

16. Shastry. J.L.N. Dravyaguna Vijnana. Edition 2006 reprint. Varanasi: Chaukhambha Orientalia;Vol 2 - 510 pp.

17. Shri Sharma Sadananda. Rasa Tarangini. Hindi translation \& Edited by Pandit Kashinath Shastri.

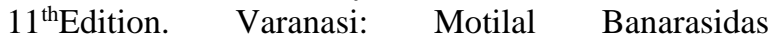
Publication; 2004. $5^{\text {th }}$ Taranga, Verses 106-108.

18. Trivedi SC, Bhatt OK. Tamrabhasma \& somnathi Tamra bhasma (a comparative clinical study). PG dissertation submitted to Gujarat Ayurved University, Jamnagar;1964-1965.

19. Wadodkar DS, SharmaHS, Pillai KU. A comparative study of media in the preparation of Tamra Bhasma with special reference to Tamaka shvasa. PG dissertation submitted to Gujarat Ayurved University, Jamnagar;1988.

20. https://doi.org/10.1016/j.fitote.2013.05.012

21. https://doi.org/10.1016/S0378-8741(99)00165-8

22. https://www.ncbi.nlm.nih.gov/pmc/articles/PMC6647 $\underline{873 /}$

\section{Source of Support: Nil \\ Conflict of Interest: None Declared}

How to cite this URL: Priyanka. B. Patil et al:Rudra Parpati: An Ayurvedic Herbo - Mineral Drug Review. International Ayurvedic Medical Journal \{online\} 2021 \{cited August 2021\} Available from: http://www.iamj.in/posts/images/upload/1819_1823.pdf 